\title{
Coherence of European Union Actions at the UN Human Rights Council and the Council of Europe
}

Anatoly Boyashov

Bielefeld University, Germany

\begin{abstract}
The current methodological debates on the EU external actions at international organisations raise the issue of the EU coherence. The scholarship tends to focus on EU vertical and horizontal coherence in various policies, making the EU internal coordination central in the analysis. Neither horizontal nor vertical EU coherence leads to understanding why the EU is accused of "double standards". Little research explores the external contestation as a pivotal matter of the EU effectiveness, performance, actorness. It appears promising to make the EU action coherent over various multilateral bodies. This paper argues that the external environment is the key element for the external coherence of the EU action at the UN Human Rights Council (HRC) and the Council of Europe (CoE). It answers the research question: how to measure external coherence in $\mathrm{EU}$ action at the $\mathrm{HRC} / \mathrm{CoE}$ ? The proposed indicators are the following: 1) coherence in references to the UN/CoE and to the EU founding treaties and pivotal documents on human rights; 2 ) degree of external support/contestation for the EU objectives at the $\mathrm{HRC} / \mathrm{CoE} ; 3$ ) degree of coherence of EU external representation to the $\mathrm{HRC} / \mathrm{CoE}$; 4) degree of coherence in formulating priorities and using instruments at the $\mathrm{HRC} / \mathrm{CoE}$. The paper provides the assessment by the UN, EU and non-EU experts of the EU external coherence, which is followed by policy recommendations.
\end{abstract}

Key words: European Union, coherence, human rights, United Nations, Council of Europe.

ear 2017 has brought new insights to analysis of the EU action at international organisations. The EU Member states achieved internal agreement to accuse China of human rights violations but did not succeed in implementing this 
decision at the $35^{\text {th }}$ Regular Session of the UN Human Rights Council. While the EU put much effort in building transatlantic coalition on that problem, Greece blocked the «final» EU statement.

Mass media insisted on the Chinese investments in the Greek maritime infrastructure to be the pivotal cause for this case ${ }^{1}$. In other words, it is as if Chinese were to be blamed for the EU failure. The point of departure of this article is that the causeand-effect relationship is more complex. The opposition to the "country-specific» initiatives and «naming-and-shaming» strategy has been widespread and existed long before $2017^{2}$. These initiatives are not applied to all parts of the world equally. They cause politicization of human rights and degrade international consensus. The issue is that neither the US nor the EU take the opposition to such initiatives into consideration, which, in turn, might lead to malfunctioning of international organisations acting as the fora for international cooperation in human rights.

One of the issues is the lack of coherence and consistency in the EU human rights promotion $[2 ; 9 ; 10]$. This paper addresses this problem with respect to international organisations.

The terms "coherence» and «consistency» are used as equivalents in the English and French versions of the Treaty of the European Union (TEU) and the Treaty on the Functioning of the European Union (TFEU). Conceptual differences between these terms have little relevance for the research question. It is generally assumed that the terms are understood as synonyms [10, p. 105-106].

The article explores the coherence of the EU actions across two international organisations: the UN Human Rights Council (HRC) and the Council of Europe (CoE). This article deals with the following question: how to measure external coherence in the EU action at the HRC/CoE?

The article focuses on the analysis of coherence of the EU external action in human rights promotion. Despite the term "coherence" is widely used in policy-making language, the methodological issue of coherence lies in absence of agreement on the definition of this term, neither in academia, nor in the EU institutions or institutional bodies. In addition to that, the academic literature suggests more terms to be applied to the analysis of the EU external action at international organisations: actorness, effectiveness, performance $[4 ; 16 ; 21]$.

The article applies to the concept of "coherence" due to the following arguments. Firstly, this article critically assesses the absence of measurement criteria for the analysis of the EU external action. The approaches, developed under the concepts of "actorness", "effectiveness", "performance", "coherence", do not suggest a sustainable measurement criteria. For example, the scholarship differentiates between the vertical

\footnotetext{
1 Greece Blocks EU Statement on China Human Rights at U.N. Reuters. Robin Emmott, Angeliki Koutantou. June 18, 2017 [Электронный ресурс]. URL: https://www.reuters.com/article/us-eu-un-rights/greece-blocks-eu-statement-on-chinahuman-rights-at-u-n-idUSKBN1990FP (дата обращения: 03.05.2019).

2 Speakers Warn against Politicization of Human Rights Issues on United Nations Agenda, as Third Committee Continues Wide-ranging Debate. UN Press Release. Third Committee. $28^{\text {th }} \& 29^{\text {th }}$ Meetings (AM \& PM). GA/SHC/3929. October 28, 2008 [Электронный ресурс]. URL: https://www.un.org/press/en/2008/gashc3929.doc.htm (дата обращения: 03.05.2019).
} 
"coherence" elated to policy implementation and to the horizontal coherence related to the deciding institutions or institutional bodies across the policy fields [10, p. 107].

The concept of "actorness" comprises three main elements without concrete criteria for measurement: 1) presence as "...the ability of the EU, by virtue of its existence, to exert influence beyond its borders" [15, p. 266]; 2) opportunity as "structural context of EU action including factors in the external environment of ideas and events which constrain or enable actorness" [4, p. 24]; 3) capability as the "...internal context of EU external action or inaction; ... ability to capitalize on presence or respond to opportunity" [4, p. 29]. The concepts of "effectiveness" and "performance" have been defined mainly as "goal attainment" and "problem-solving" [21]. The assessment on the basis of these concepts without systemic empirical criteria could lead to normative conclusions. Application of these terms to the concrete cases does not offer sustainability in the EU external action measuring and for predicting its outcomes. Therefore, one of the article's objectives is to propose the concrete measurement criteria for the EU external action in human rights promotion.

Secondly, the article critically assesses the methodological distinction between the horizontal coherence and the vertical one. Besides the lack of empirical focus, such a distinction avoids the considerable analysis of the external context for the EU actions, the structure of an international organisation or the current prospects of nonEU states, or non-EU international bodies.

The focus is still important as illustrated by the above mentioned Chinese case. The external context is sensitive towards the EU human rights promotion: particular states, regional organisations and groupings (like Non-Aligned Movement). These elements often characterise it as a "double-standards" action. The argument of the external actors is that the EU lacks for coherence in the external application of its human rights policies: across regions, countries, international organisations. Therefore, the article introduces the term of "external coherence" and focuses on its empirical analysis.

Thirdly, the article addresses the lack of comparative empirical focus on the current concepts of "coherence", "actorness", "effectiveness", "performance". These concepts rarely introduce comparative empirical measurements, however, they are often applied in single case-studies. The article proposes four measurable criteria to assess the EU external coherence in human rights promotion at international organisations. To do it, it conducts the comparative research of external coherence of the EU at the UN Human Rights Council and the Council of Europe on the basis of: 1) coherence in references to the $\mathrm{UN} / \mathrm{CoE}$ and respective sources on human rights protection in the EU law; 2) degree of external support/contestation for the EU objectives at the $\mathrm{HRC} / \mathrm{CoE} ; 3$ ) degree of coherence of the EU external representation to the $\mathrm{HRC} / \mathrm{CoE}$, and 4) degree of coherence in formulating priorities and using instruments at the $\mathrm{HRC} / \mathrm{CoE}$.

These measurements are followed by the policy recommendations aiming at overcoming alleged "double standards" of the EU human rights promotion. 


\section{Case-selection, Scope of the Research and Methodology}

The first methodological choice is to analyse the EU external actions in human rights promotion. Why not development policy or humanitarian aid? First of all, the question of the human rights is a guiding principle of the EU external action, it is "at heart" of the EU external action. The EU identifies itself as a "strategic human rights actor" and a "multilateral actor" [22, p. 157]. Notwithstanding, the EU, the HRC and the $\mathrm{CoE}$ are to a certain extent "competitors" in the domain of human rights promotion.

The second methodological choice is to compare the EU actions in human rights promotion at international organisations. Why international organisations, but not regions or countries? International organisations bear an important function to set norms of international cooperation and standards for global governance [1, p. 349]. International organisations enable "socialisation" of other actors in world politics [3].

The third methodological choice is to compare EU human rights promotion at two intergovernmental bodies: the UN Human Rights Council and the Council of Europe. The choice for the HRC and the $\mathrm{CoE}$ is justified by their role in the worldwide human rights promotion and by the strategic importance given to these institutions by the $\mathrm{EU}^{3}$. The EU gives priority to the support for HRC and to the cooperation with the CoE in both action plans on human rights and democracy in 2012-2014 and 2015-2019. The EU explicitly stressed its support for the HRC and the CoE in "Global Strategy" as the mechanisms for human rights promotion. The EU aims at promoting a rules-based global order with the $\mathrm{UN}$ at its core. As for the $\mathrm{CoE}$, the EU recognizes it as a benchmark for human rights promotion.

In addition to that, the similarity between the HRC and the CoE structures enhances the comparison: 1) both the UN and the CoE are the international institutions with the intergovernmental nature; 2) the EU member states are also members of the $\mathrm{UN}$ and the CoE; 3) the external context at the HRC and at the CoE includes the other non-EU member states; 4) the HRC consists of 47 members and the CoE consists of 47 members; 5) both the HRC and the $\mathrm{CoE}$ aim at human rights promotion, the HRC at the global level, the $\mathrm{CoE}$ - at the regional level; 6) the priorities of the EU human rights promotion at the $\mathrm{HRC}$ and the $\mathrm{CoE}$ are significantly overlapping.

This paper contributes to the research by its comparative methodological design. The current studies of the EU actions at the HRC focus on the EU internal divergence and on the external effectiveness [18], groupings contestations at the HRC [5], attainment of the EU priorities [21], the EU instruments and external action [11, p. 387]. Existing EU studies at the CoE are dominated by the EU non-accession to the European Convention on Human Rights $[7 ; 20 ; 12]$. The relevant studies for this paper are the research by Kolb (2013) on the inter-organizational relations

\footnotetext{
3 Joint Communication to the European Parliament and the Council, Human Rights and Democracy at the Heart of EU External Action - Towards a More Effective Approach. European Commission, Brussels, 02.12.2011, COM(2011) 886 final.
} 
between the EU and the CoE, the study of "technical specialization" for the EU to promote human rights for European Neighbourhood Policy and for the EU-candidate states [19, p. 170], the concurrence and the cooperation between the EU and the CoE [6].

The research was conducted by the method of semi-structured interviewing. The respondents $(\mathrm{N}=13)$ were chosen on the basis of snowball sampling ${ }^{4}$. The sampling method is justified as experts in this field are difficult to reach. The risk of this method is a possibility to address questions to one sub-group of experts who know one another, hence tend to recommend their colleagues. The other challenge is that an expert being on duty may give "formal" abstract answers. If not overcome, these two risks may lead to biased conclusions. Therefore, the interviews were conducted under the Chatham House Rule. Plus, the sampling method was applied only until a certain sub-group of experts finishes to provide an the interviewer with new information. Sub-groups of experts were designed on the basis of geographical and professional representation; 1) the EU institutions and institutional bodies; 2) the HRC and CoE Secretariats; $3)$ the EU state foreign ministries; 4) the non-EU state foreign ministries; 5) NGOs; 6) universities.

The respondents were invited to answer three sections of questions on the basis of proposed indicators: 1) coherence in references to the $\mathrm{UN} / \mathrm{CoE}$ and respective sources on the human rights protection in the EU law; 2) degree of external support/contestation for the EU objectives at the $\mathrm{HRC} / \mathrm{CoE} ; 3$ ) degree of coherence of the EU external representation to the $\mathrm{HRC} / \mathrm{CoE}$, and 4) degree of coherence in formulating priorities and using instruments at the $\mathrm{HRC} / \mathrm{CoE}$. The experts were met in Bruges, Brussels, Geneva during the period from the $9^{\text {th }}$ of November, 2016 till the $2^{\text {nd }}$ of May, 2017. Two interviews were held via phone calls, one - per e-mail. There occurred one inclination in the sample - 8 out of 13 experts dealing with the UN HRC. The interviews were not recorded, but transcribed after the meetings. The findings of the paper answer to the research question: how to measure external coherence in EU action at the HRC/CoE? To answer the research question the findings were assessed with the help of the expert opinions.

\footnotetext{
4 Interview 1. Legal secretary at the CJEU, Bruges, 9/11/2016;

Interview 2. Researcher, Katholieke Universiteit Leuven, Leuven, 24/02/2017;

Interview 3. Former counsellor, European Commission Delegation to the UN in New York, Bruges, 9/03/2017;

Interview 4. Former counsellor, EU Delegation to the UN in New York, Bruges, 10/032017;

Interview 5. Registry servant, the CoE, via phone, 14/03/2017;

Interview 6. Representative of an NGO accredited for the HRC Regular Session, Geneva, 21/03/2017;

Interview 7. Head of Unit, the UNHCR, Geneva, 22/03/2017;

Interview 8. State diplomat, Permanent Mission to the UN Office in Geneva, via mail, 28/03/2017;

Interview 9. Former state diplomat, Permanent Mission to the UN Office in Geneva, Brussels, 10/04/2017;

Interview 10. Béla Szombati, Minister Counsellor, Head of the Human Rights Section, EU Delegation to the UN and other international organisations in Geneva, via phone, 25/04/2017;

Interview 11. NGO representative in Strasbourg, via phone, 27/04/2017;

Interview 12. State diplomat, Permanent Mission to the CoE, via mail, 2/05/2017;

Interview 13. Eric Tistounet, Chief of the Human Rights Council and Treaty Mechanisms Division, Office of the United Nations High Commissioner for Human Rights, via phone, 2/05/2017.
} 


\section{Coherence in references to the $\mathrm{UN} / \mathrm{CoE}$ and respective sources on human rights protection in the EU law}

The EU is highly aspirational on its role in human rights promotion both at the HRC and the CoE. The limitations pointed by the experts are: 1) the high aspirations laid down in the Treaties lack for references to sources of international human rights law; 2) introduction of human rights as founding principles/objectives; 3) limited applicability of the Charter for Fundamental Rights and "duplication" of norms of the European Convention for Human Rights.

The Preamble of the TEU stresses the attachment of the EU to respect for human rights and fundamental freedoms with reference to the "inheritance of Europe". Human rights are regarded as a foundational value of the EU stipulated by Art. 2, TEU. Art. 5 TEU refers to the protection of human rights "... in its [EU] relations with the wider world..." and respect for the principles of the United Nations Charter that, in its turn, has at the core the realization of human rights for all without distinction as to race, sex, language or religion.

The EU identity as a human rights actor at the $\mathrm{CoE}$ is strong due to numerous substantial references in the Treaties to the Council of Europe, the European Convention and regional human rights promotion. Art. 6, para 3 TEU enables strong EU presence in this field noting: "Fundamental rights, as guaranteed by the [Convention] ... shall constitute general principles of the Union's law". The Charter of Fundamental Rights recognizes the fundamental rights and principles laid down in the European Convention.

Although the TEU does not have explicit references to human rights in its provisions on the Common Foreign and Security Policy (CFSP), the EU external action in CFSP matters is guided by Art. $21 \mathrm{TEU}$ as it refers to human rights as a guiding principle. In the very first paragraph human rights as a principle that inspired the creation of the EU are explicitly linked with the objective to respect the principles of the UN Chapter. To promote human rights externally the EU aims at the cooperation with global organizations that share the same values. The reference to the UN framework is explicit in the second paragraph of Art. 21: the EU “... shall promote multilateral solutions to common problems [also in the domain of human rights], in particular in the framework of the United Nations". Art. 21 also has an explicit reference to the human rights promotion in accordance with the purposes and principles of the Charter of the UN in para 2(c) and an explicit accent on the EU objective to promote multilateral cooperation and "good global governance" in para 2(h).

Art. 21 TEU enables human rights promotion as an objective of EU external action to be applied across all policies. Art. 21 TEU explicitly emphasizes the human rights as a guiding principle of the EU action on the international scene and stipulates that the EU shall develop cooperation with regional organizations that share the same principles, notably, the "... universality and indivisibility of human rights and fundamental freedoms, respect for human dignity, the principles of equality and solidarity...." 
Art. 220 TFEU explicitly refers to the CoE as an organization that the EU shall establish all appropriate forms of cooperation with. As for the UN, the EU and the member states "... shall cooperate with ... competent international organizations" (Art. 212, para 3, TFEU). In addition to that, Art. 220 TFEU stipulates that the EU “...shall establish all appropriate forms of cooperation with the organs of the UN and its specialized agencies..." The EU is highly aspirational on its identity as an exclusive actor in human rights promotion at the $\mathrm{HRC}$ and the $\mathrm{CoE}$, and the respondents stressed that.

\section{Degree of external support/contestation for the EU objectives at the HRC/CoE}

The external contestation/support is not able to make the EU actions in the domain of human rights more or less coherent. It is up to the EU internal coordination processes to make its action coherent across various international organisations. Notwithstanding, external contestation could perform as a remote factor for the EU actions. It could serve as an indicator once incoherence augments. The incoherence of the EU actions, in its turn, degrades politicization of human rights, which leads to "double-standards" issue at the human rights, as observed by Zhuleva and Lazutina [25, p. 205].

The external context exerts more pressure at the HRC than at the CoE. In general, the EU priorities in human rights are not contested at the CoE. The main role is played by the European Court of Human Rights (ECHR). When it delivers a judgment and the contestation occurs, the non-EU states contest the ECHR for progressive interpretation of the Convention or politicization of an issue. The contestation does not refer to the EU, since the ECHR unites the constitutional traditions of the CoE member states. According to the interviewees, the contestation towards the EU has evolved after the negotiations on the EU accession to the European convention: the EU proposed to amend the rules of the procedure at the Committee of Ministers to have voting rights, which was contested, at first, by Switzerland, Russia and Turkey in September 2012, and further, by 16 non-EU members at the CoE in January 2013. The other part of contestation comes on the point that not all EU member states have ratified all the protocols to the European Convention or the key CoE conventions: e.g. the Protocol No 12 on prohibition of discrimination or the European Social Charter.

Moreover, according to the interviews, the EU member states act like a "bloc" in the Committee of Ministers supervising the ECHR judgments: e.g. the EU prevents non-EU states from referring to the Court for the interpretation of the judgment. The case-law of the ECHR has developed in such a way that corresponds to the values of the EU, hence coincides with the EU priorities for the human rights promotion at the CoE.

Concerns are raised since some EU member states have not ratified the $\mathrm{CoE}$ conventions related to the EU priorities, e.g. the European Convention on the Exercise of Children's Rights. The joint EU-CoE programs meet contestation from 19 non-EU states rarely: the EU-CoE joint programs on promotion of minori- 
ties rights are contested because the EU allegedly does not have the internal legal framework.

The main problem is the fact that the $\mathrm{CoE}$ and the EU have the organisational "self-interest", an "interest-based factor" as Kolb notes it [13, p. 191]. The EU has started to identify itself as a distinct human rights organisation since 1990s, which caused a degree of contestation from the CoE. The mandate, granted to the EU Fundamental Rights Agency (EU FRA) by the Commission, was contested as interfering into the core competence of the CoE [16, p. 198-199]. The agreement between the EU FRA and the CoE of 2008 intended to solve this issue: e.g. EU FRA consults the CoE on technical matters and the CoE representative holds voting rights at almost all EU FRA meetings. However, the CoE remains attentive to the scope of the EU FRA actions, especially, in regard with the extension of the EU FRA mandate, to increase its budget.

The EU recognizes the benchmarking role of the CoE in (at the) ENP. The CoE human rights regime is intertwined with the EU law: e.g. the EU Charter included a lot from the European Social Charter, it refers to the European Convention. The dialogue between judges of the Court of Justice (CJEU) and the ECHR was initiated. The Committee of Ministers provided to its Steering Committee for Human rights an ad hoc mandate to cooperate with the European Commission on elaboration of the necessary legal instrument for the EU accession. With all those limitations, the contestation for the $\mathrm{EU}$ actions at the $\mathrm{CoE}$ is not strong because the $\mathrm{EU}$ and the $\mathrm{CoE}$ are involved into the constant dialogue at various levels, plus, the contestation from non-EU actors at the $\mathrm{CoE}$ is shared between the $\mathrm{EU}$ and the CoE.

However, the external context of the HRC exerts more contestation on the EU. As observed by Smith, the EU member states being the members of the HRC don't incline to vote together if there might occur a request for a voting procedure [17]. The requests for a vote come often from the non-EU states and the large coalitions: "Non-aligned movement", "Like Minded Group", the African Group, the Arab Group, the Organization for Islamic Cooperation. While the EU priorities for the ENP countries receive contestation rarely at the $\mathrm{CoE}$ - the EU priorities for the ENP states regularly receive contestation at the UN HRC, notably, the resolutions for the technical cooperation with Georgia and the Ukraine. The EU states take these two resolutions without "naming-and-shaming" - under Item 10 of the HRC agenda ("Technical assistance and capacity-building"). On the contrary, the EU takes and promotes the resolutions on Belarus, Iran and Syria under the other Item 4 of the HRC agenda, which meet the opposition as well regularly. The EU priority to protect human rights defenders does meet the contestation in the form of additional amendments to resolutions, however, the progressive interpretation of sub-groups of defenders like "environmental human rights defenders" - does receive contestation. The elimination of death penalty - the top priority for the EU - encounter resistance from the US, China, the certain Arab and African states. Severe contestation receives the EU priority for establishing the cooperation with the UN and the UN HRC Special Procedures due to the EU inability to compromise. Moreover, some resolutions proposed by non-EU actors effec- 
tively promote indivisibility and universality of human rights: the resolutions on the effects of foreign debt on human rights, the illicit financial flows and human rights, family protection, traditional values, the responsibility of transnational companies for the human rights violations, integrity of the judicial system, the right to develop, etc. The states contesting the EU initiatives can amend the resolutions with or without membership or can always request a vote through their ally as a member of the HRC. The EU tries to compromise its priorities with the priorities of the other groupings for the better implementation of its resolutions in the future.

\section{Degree of coherence in formulating priorities and using instruments at the $\mathrm{HRC} / \mathrm{CoE}$}

As noted by the interviewees, the EU priorities lack for external cohesion: the priorities vary from time to time, which are context-oriented, however, they vary from one organisation to another, from one region to the other, from one country to the other. At the same time, the EU external representation is complex, but coherent. The EU uses the extensive coordination to formulate objectives as in Brussels (COSCE, COHOM, CONUN), also and in Geneva and Strasbourg (EU Delegations). The implementation of the priorities involves the actions of the EU member states, the EU institutions, the EU FRA, the EU Delegations and the EEAS in the areas of their responsibility. The EU reaches its objectives through the internal coordination, the initiatives on the HRC/CoE agenda (like in "Prevention of human rights violations"), negotiations with non-EU members, involvement of some NGOs, and inter-organizational cooperation with the $\mathrm{HRC} / \mathrm{CoE}$ Secretariats.

The Memorandum of Understanding serves as the main legal basis for the EU human rights promotion at the $\mathrm{CoE}$. The Delegation of the $\mathrm{EU}$ to the $\mathrm{CoE}$ represents the EU. The EU is also represented by the Rotating Presidency, incoming Rotating Presidency, the Commission, the General Secretariat of the Council, the EU Delegation at the $\mathrm{CoE}$ - Article 36 Troika (CATS) meetings. The EU also sends its experts to the $\mathrm{CoE}$ intergovernmental meetings, usually, the EU is represented there by the Commission, the EU Delegation, the EU FRA or the other body related to thematic human rights issues. The EU Special Representative on human rights meets with the CoE Secretary General, the Commissioner for Human Rights, with the representatives of the ECHR and the European Committee on Social Rights.

The EU instruments used to achieve its priorities are the following: the EU-CoE joint programs, the EU-CoE Programmatic Cooperation Framework (PCF) - since June 2017 Partnership for Good Governance, the EU FRA cooperation with the CoE. The EU is a party to several the CoE treaties, the European Commission has the status of an observer to the Governmental Committee of the European Social Charter, the Standing Committee on the European Convention of the Exercise of Children's Rights. Diverse types of participation provide the strong EU capability to reach its objectives at the CoE. For example, the CoE Strategy for the Rights of the Child (2016-2021) and 
the Gender Equality Strategy (2014-2020) were adopted by closest cooperation with the EU. The EU also adopts its strategic documents in human rights promotion, e.g. the EU Human Rights Guidelines, in close cooperation with the CoE.

In 2014-2016 the EU human rights promotion was enhanced significantly with the adoption of EU-CoE Statement of Intent leading to EU-CoE cooperation in Eastern Neighborhood and Southern Neighborhood Region - "Programmatic Cooperation Framework" (PCF) through annual programs of activities ${ }^{5}$. The instrument is realised as a part of the European Neighborhood Instrument (ENI). The instrument focuses on: 1) enhancement of the European Human Rights implementation of standards at the regional and national level; 2) protection of the national and the ethnic minorities' rights; 3 ) promotion of the human rights, the equality and the human dignity.

Finally, the EU external representation, the EU variety of instruments, its ability to "upgrade" the priorities in response to the structural context - to strengthen the EU human rights promotion at the CoE. However, the EU and the EU member states have not accessed to the important $\mathrm{CoE}$ treaties in relation to the EU priorities, the EU member states still have their reservations to the treatie; financial contribution to the EU-CoE joint programs is small.

As for the HRC, the EU has the status of observer before the HRC based on the UN GA resolution 65/276, which allows the EU to speak, to deliver statements and interventions, to attend formal meetings. This status allows less than the full membership: the EU speaks after the states and seats aside. The observers enjoy 1-2 minutes of speaking. As observed by the scholars, the improvement of the EU status at the HRC could have been realised through the extension of the application of the UN GA Resolution 65/276 to the HRC, giving the EU status of an enhanced observer [23, p. 55].

The vast network comprising the EU Delegation and the diplomatic services of EU member states allows the EU to cover the whole institutional package of the HRC. The EU external representation to the HRC can be regarded as a complex system with the EU Delegation at the HRC, the EU member states, and the rotating presidency acting together [24, p. 61]. The coordination process strengthens the EU action in Geneva as it enables the EU and the EU member states for the burden-sharing practices at the HRC. However, the EU internal negotiation takes a lot of time due to the issues of "patchwork representation" [11; 14, p. 162]. Due to varying EU member state policies related to human rights, the EU coordinated position often presents the "lowest common denominator" between the member states.

The comparison of the EU external representation and instruments at the CoE and the HRC reveal a certain degree of incoherence. Table 1 demonstrates that the EU priorities in human rights promotion at the HRC and $\mathrm{CoE}$ diverge. The general trend for the $\mathrm{EU}$ is to make thematic human rights promotion at the $\mathrm{HRC}$ and

\footnotetext{
${ }^{5}$ Statement of Intent for the Cooperation between the Council of Europe and the European Commission in the EU Enlargement Region and the Eastern Partnership and the Southern Mediterranean Countries (EU Neighbourhood Region). Council of Europe and European Commission, 2014, Brussels [Электронный ресурc]. URL: https://rm.coe.int/CoERMPublicCommonSearchServices/DisplayDCTMContent?documentld=090000168066b99e (дата обращения: 02.05.2019).
} 
the CoE more coherent, especially, in protection of the LGBT community, migrants, ensuring the social, economic and cultural rights. The priority to respect the social, economic and cultural rights was finally set at the HRC and the CoE in 2016. The considerable level of incoherence is found in setting priorities for climate and human rights (set only in 2016 and only before the HRC), rights of migrants (set only in 2016 and only before the HRC), protection of Roma (set only before the CoE), human trafficking (set for the CoE, was mentioned for the HRC in 2015), tackling of the terrorist content on the internet and at the social media (set for the CoE only in 2016).

Table 1. The thematic EU Priorities for the Human Rights Promotion at the UN HRC and the CoE

\begin{tabular}{|l|c|c|c|c|c|c|}
\hline \multirow{2}{*}{ Thematic Priority } & \multicolumn{2}{|c|}{$\mathbf{2 0 1 4}$} & \multicolumn{2}{|c|}{2015} & \multicolumn{2}{|c|}{2016} \\
\cline { 2 - 7 } & HRC & CoE & HRC & CoE & HRC & CoE \\
\hline Human rights defenders & Yes & Yes & Yes & Yes & Yes & Yes \\
\hline Abolition of the death penalty & Yes & Yes & Yes & Yes & Yes & Yes \\
\hline Freedom of religion or belief & Yes & Yes & Yes & Yes & Yes & Yes \\
\hline Child's rights & Yes & Yes & Yes & Yes & Yes & Yes \\
\hline Women's rights & Yes & Yes & Yes & Yes & Yes & Yes \\
\hline Freedom of expression/ of peaceful assembly & Yes & Yes & Yes & Yes & Yes & Yes \\
\hline Tackling degrading or inhuman treatment & Yes & Yes & Yes & Yes & Yes & Yes \\
\hline Protection of LGBT & Yes & Yes & No & Yes & No & Yes \\
\hline Fight against racism & Yes & Yes & Yes & Yes & Yes & Yes \\
\hline Protection of migrants & No & No & No & No & Yes & No \\
\hline Economic, social and cultural rights & Yes & No & Yes & No & Yes & Yes \\
\hline Business and human rights & Yes & Yes & Yes & Yes & Yes & Yes \\
\hline Climate and human rights & No & No & No & No & Yes & No \\
\hline Protection of Roma & No & Yes & No & Yes & No & Yes \\
\hline Human trafficking & No & Yes & Yes & Yes & No & Yes \\
\hline $\begin{array}{l}\text { Tackling the terrorist content on the internet and at } \\
\text { the social media }\end{array}$ & No & No & No & No & No & Yes \\
\hline Protection of the disabled people & No & No & No & No & No & No \\
\hline
\end{tabular}

Source: Register of the European Council and the Council of the EU. URL: http://www. consilium.europa.eu/register/en/content/int/?lang=enety $p=A D V$; Council of the EU, Council conclusions on EU priorities at the UN Human Rights Fora, Press Office, FAC Meeting, Brussels, 10 February 2014. Council of the EU, Council Conclusions on EU priorities at UN Human Rights Fora in 2015, Brussels, 9 February 2015, 5927/15. Council of the EU, EU Priorities at UN Human Rights Fora in 2016, Brussels, 15 February 2016, 6012/16. Council of the EU, EU priorities for cooperation with the Council of Europe in 2014-2015, 16444/13, Brussels, 19 November 2013. Council of the EU, EU priorities for cooperation with the Council of Europe in 2016-2017, 14919/15, Brussels, 15 December 2015. Compiled by the author. 


\section{The concurrency at the foreign policy and the Recommendations}

The analysis suggests that the EU lacks for the concurrency at the foreign policy in setting the priorities at the similar thematic domain for the HRC and the CoE. The experts dealing with the UN HRC tend to emphasize the external contestation for the EU priorities at the UN. The remote cause for this is the EU incoherence in setting thematic priorities at the human rights promotion at the HRC and the CoE.

According to the majority of interviewees the $\mathrm{EU}$ is more coherent in setting priorities for certain country situations. However, as illustrated by Table 1, the incoherence in setting priorities opens a room for non-EU alliances to exert pressure on the EU and accuses it of applying "double-standards" across the global and regional structures, the thematic organisations (the World Health Organisation and the $\mathrm{Hu}$ man Rights Council).

How can the EU improve its coherence? During 2014-2016 the EU priorities at the HRC and the CoE varied on the following thematic issues: the protection of LGBT, the migrants, Roma; the promotion of economic, the social and cultural rights; the climate and the human rights; the ensuring respect for the human rights and tackling the human trafficking and terrorist content in social media. The EU could adopt/renew guidelines on these matters and organise additional coordinating meetings. The next step would be to mainstream human rights across various policies in the same manner.

The next explanation for the EU external incoherence is the structural differences between the HRC and the CoE. To put it roughly, the HRC involves more parties with various attitudes to the universality of human rights. Therefore, the EU tends to be more flexible at the HRC and to refuse the ambiguous priorities set for the CoE.

As for the thematic issues, the EU is highly aspirational in human rights promotion in third states, while it does not pay the same level of attention to the protection of human rights in the EU and their coherence, e.g. in the sphere of protection of the social rights. The non-EU actors contest the EU initiatives on that ground stressing that the EU does not consider economic, social, cultural particularities. Further, the EU aims at putting human rights at the heart of its external policies, however, it is ready to refuse this aim when there is a risk for the EU economic or political interests, notably, the EU does not invoke "human rights essential elements" in trade agreements. The EU bureaucracy is complex; it acts together with the EU member states in human rights promotion, which creates a "patchwork". The EU institutions are not accountable for human rights violations. Finally, the EU priorities for the human rights promotion at the $\mathrm{HRC}$ and at the $\mathrm{CoE}$ are not always consistent across time.

Degree of contestation to the EU identity from non-EU actors at the HRC is higher than at the CoE. While no actor at the HRC would doubt the universality of human rights, the HRC creates room for proposing alternative interpretations of that universality in the form of resolutions. The structural regional divisions of the United Nations enable contestation from political groupings, which does not occur at the CoE. The EU acting as a "bloc" is less visible at the CoE. 
Next, the voluntary contributions to the Office of the High Commissioner for $\mathrm{Hu}$ man Rights (OHCHR) budget - i.e. to HRC Special Procedures - are contested by non-EU actors at the HRC, however, the voluntary contributions to the CoE through EU-CoE joint programs cost less, hence are less contested. In addition to that, the EU activates its assistance "through" the HRC or the OHCHR even if the consent of recipient states is not in place. In the case of the CoE, even if EU initiatives are contested, they are implemented through the structure of the CoE, therefore, the CoE would be contested in this case.

On the basis of the conclusions, the policy recommendations refer mainly to improvement of external coherence. This paper is far from insisting that external coherence depends fully on the EU. However, implementation of these recommendations may augment the coherence of EU human rights promotion across international organisations, enhance international consensus and strengthen policy dialogue.

1. For Commission, Council, member states, EP - to compare the secondary legislation establishing financial instruments related to the EU priorities in human rights promotion at the HRC and the CoE, notably, in the sphere of protection of minorities' rights, anti-discrimination, economic, social and cultural rights, rights of migrants, climate-related human rights, trafficking in human beings, tackling terrorist content in social media.

2. For Council, EU Delegations, member states - to aim at "less strong" compromised resolutions and their better implementation at the HRC; to increase crossreginal cooperation, to build "new" coalitions in this regard. For Commission, Council, EP, CJEU, EEAS - to assess the possibility and accede if possible the global and regional treaties related to the EU priorities in human rights promotion; special attention should be given to the European Social Charter, the International Covenant on Economic, Social and Cultural Rights. For Commission - to assess the coherence of the EU policies and priorities with the agenda of "Business and human rights" and "Human rights and environment".

3. For Council, EU Member states - to make the Human Rights Guidelines more coherent with the priorities and outcomes of the EU action at the HRC and the CoE in 2014-2016, especially, considering data protection, protection of migrants, economic, social and cultural rights; to ensure implementation of the Guidelines by the member states.

4. For Commission, EEAS - to create a comprehensive system with common criteria for all actors involved into the EU external action with the aim to assess their quality and final impact on the ground in human rights promotion across time.

\section{References:}

1. Abbott K., Genschel Ph., Snidal D., Zangl B. International Organizations as Orchestrators. Cambridge, Cambridge University Press, 2015. 430 p.
2. Abrisketa J., Churruca Muguruza C., de la Cruz C., García L., Márquez C., Morondo Taramundi D., Nagore M., Sosa L., Timmer A. Human Rights 
Priorities in the European Union's External and Internal Policies: An Assessment of Consistency with a Special Focus on Vulnerable Groups. FRAME Report 12.2. Brussels, 2015. 228 p.

3. Barnett M., Finnemore M. Rules for the World. International Organizations in Global Politics. New York, Cornell University Press, 2004. 240 p.

4. Bretherton Ch., Vogler J. The European Union as a Global Actor. London, Routledge, 2006. 316 p.

5. Chané A., Hauser A., Jaraczewski J., Jóźwicki W., Kędzia Z., Šimáková M., Suchocka H., Wallace S. EU Engagement with other European Regional Organisations. European Commission. Work Package No. 5 - Deliverable no. 2, Large-Scale FP7 Collaborative Project, GA No. 320000, 2016.

6. Chané A., Sharma A. Universal Human Rights. Exploring Contestation and Consensus in the UN Human Rights Council. Human Rights \& International Legal Discourse, 2016, vol. 10, no. 2, pp. 219-247.

7. De Schutter O. Human Rights and the Rise of International Organisations: The Logic of Sliding Scales in the Law International Responsibility, in: [eds.] Jan Wouters et al., Accountability for $\mathrm{Hu}$ man Rights Violations by International Organizations. Antwerpen, Intersentia, 2011. pp. 55-129.

8. Gauttier P. Horizontal Coherence and the External Competences of the European Union. European Law Journal, 2004, vol. 10, no. 1, pp. 23-41. DOI: 10.1111/j.1468-0386.2004.00201.x

9. Gebhard C. Coherence, in: [eds.] Hill C., Smith M., International Relations and the European Union. Oxford, Oxford University Press, 2011. pp. 101-127.

10. Gómez Isa F., Churruca C., Wouters J. EU Human Rights and Democratization Policies: Achievements and Challenges. Abingdon, Oxon, Routledge, 2018. 188 p. DOI: 10.4324/9781315110769

11. Gstöhl S. "Patchwork Power" Europe: The EU's Representation in International Institutions. European Foreign Affairs Review, 2009, vol. 14, no. 3, pp. 385-403.

12. Ispolinov A. Sud Yevropeyskogo Soyuza protiv prisoyedineniya ES k Yevropeyskoy konventsii po pravam cheloveka (prichiny i sledstviya) [The European Court of Justice against the EU's Accession to the European Convention on Human Rights (Cause and Effect)] Mezhdunarodnoye pravosudiye, 2015, no. 1, pp. 118-134. (In Russian)

13. Kolb M. The European Union and the Council of Europe. Basingstoke, Palgrave Macmillan, 2013. $232 \mathrm{p}$.

14. Moiseyeva D. Vzaimodeystviye Yevropeyskogo soyuza s mezhdunarodnymi organizatsiyami $\mathrm{v}$ kontekste organizatsionnoy teorii [The Interac- tion of the European Union with International Organizations in the Context of Organizational Theory]. Vestnik Permskogo universiteta, 2018, vol. 12, no. 4, pp. 153-165. (In Russian)

15. Niemann A., Bretherton Ch. EU External Policy at the Crossroads: The Challenge of Actorness and Effectiveness. International Relations, 2013, vol. 27, no. 3, pp. 261-275. DOI: $10.1177 / 0047117813497306$

16. Schumaher B. The Influence of the Council of Europe on the European Union: Resource Exchange and Domain Restriction as Venues for Inter-Institutional Influence, in: [eds.] Costa O., Jørgensen, K., The Influence of International Institutions on the EU. Basingstoke, Palgrave Macmillan, 2012. pp. 186-206. DOI: $10.1057 / 9780230369894$

17. Smith K. EU Member States at the UN: A Case of Europeanization arrested. Journal of Common Market Studies, 2017, vol. 55, no. 3, pp. 628-644.

18. Smith K. The European Union and the Politics of Legitimisation at the United Nations. European Foreign Affairs Review, 2013, vol. 18, no. 1, pp. 63 80. DOI: $10.1111 /$ jcms. 12504

19. Stivachtis Y., Habegger M. The Council of Europe: The Institutional Limits of Contemporary European International Society. Journal of European Integration, 2011, vol. 33, no. 2, pp. 159-177. DOI: 10.1080/07036337.2011.543524

20. Storgaard L. EU Law Autonomy versus European Fundamental Rights Protection On Opinion 2/13 on EU Accession to the ECHR. Human Rights Law Review, 2015, vol. 15, no. 3, pp. 485-521.

21. Tuominen H. The Role of the European Union at the United Nations Human Rights Council. Helsinki, Academic Dissertation, Unigrafia, 2016. 201 p.

22. Wouters J., Chané A., Ramopoulos T. Improving the European Union's Status in the United Nations and the UN System: An Objective Without a Strategy, in: [eds.] Kaddous Ch, The European Union in International Organisations and Global Governance. Oxford, Hart Publishing, 2015. Pp. 45-74. DOI: $10.1057 / 9781137023636$

23. Wouters J., Meuwissen K. The European Union at the UN Human Rights Council: Multilateral Human Rights Protection Coming of Age. European Journal of Human Rights, 2014, no. 2, pp. 135-172.

24. Zaru D., Geurts Ch. Legal Framework of EU Participation in Global Human Rights Governance, in: [eds.] Wouters J., Bruyninckx H., Basu S., Schunz S. The European Union and Multilateral Governance. Basingstoke, Palgrave Macmillan, 2012. Pp. 49-65. DOI: 10.1057/9780230375918

25. Zhuleva M., Lazutina T. Chelovek i yego prava $v$ kontekste sovremennoy real'nosti [Man and His Rights in the Context of Modern Reality] Vest- 
nik Tomskogo gosudarstvennogo universiteta,

$10.17223 / 15617793 / 418 / 26$

2017, no. 418, pp. 202-207. (In Russian) DOI:

\title{
About the author:
}

Anatoly S. Boyashov - Research Fellow, Bielefeld University, University St., 25, 33615 Bielefeld, Germany. E-mail: anatoly.boyashov@uni-bielefeld.de.

\section{Согласованность действий Европейского союза в Совете по правам человека $\mathrm{OOH}$ и Совете Европы}

\author{
Анатолий Бояшов \\ DOI 10.24833/2071-8160-2019-3-66-159-175 \\ Билефельдский университет
}

\begin{abstract}
Вопрос согласованности (англ. coherence) действий Европейского союза в международных организациях вызывает острые дискуссии как в среде специалистов, так и в академическом сообществе. Отличие дискуссий в академическом сообществе в том, что их фокус замыкается на самом Евросоюзе: обсуждения, как правило, не выходят за рамки вертикальной (между государствами, институтами и институциональными образованиями) и горизонтальной (между различными областями политики) согласованности действий ЕС. А как же согласованность одной и той же политики в разных межправительственных организациях? Концепции вертикальной и горизонтальной согласованности избегают анализа «двойных стандартов» внешнеполитических действий ЕС в международных организациях. Исследования на базе этих концепций не рассматривают внешнюю по отношению к ЕС среду как существенный фактор, влияющий на «эффективность», «результативность» или «акторность» Евросоюза. В то время как ЕС фиксирует свои действия в международных межправительственных организациях как в высокой степени согласованные и последовательные, именно внешняя среда опровергает эти положения во взаимодействии с ЕС. Как же измерить внешнюю согласованность действий ЕС в международных межправительственных организациях, например, в Совете по правам человека ООН (СПЧ ООН) и Совете Европы? В статье предложены и апробированы следующие индикаторы для оценки степени внешней согласованности действий ЕС в международных межправительственных организациях: 1) согласованность ссылок на ООН и Совет Европы в учредительных договорах ЕС и ключевых актах, учреждающих инструменты в области прав человека; 2) степень внешней поддержки/ противодействия приоритетам ЕС в СПЧ ООН и Совете Европы; 3) степень согласованности внешних представительств ЕС в СПЧ ООН и Совете Европы; 4) степень согласованности в формулировании приоритетов и задействовании инструментов в СПЧ ООН и Совете Европы. Статья основана на результатах опроса экспертов из ООН, ЕС, а также дипломатических сотрудников ряда государств.
\end{abstract}

Ключевые слова: Европейский союз, согласованность, права человека, ООН, Совет Европы. 


\section{Список литературы}

1. Abbott K., Genschel Ph., Snidal D., Zangl B. International Organizations as Orchestrators. Cambridge: Cambridge University Press, 2015. $430 \mathrm{p}$.

2. Abrisketa J., Churruca Muguruza C., de la Cruz C., García L., Márquez C., Morondo Taramundi D., Nagore M., Sosa L., Timmer A. Human Rights Priorities in the European Union's External and Internal Policies: An Assessment of Consistency with a Special Focus on Vulnerable Groups. FRAME Report 12.2. Brussels, 2015. 228 p.

3. Barnett M., Finnemore M. Rules for the World. International Organizations in Global Politics. New York: Cornell University Press, 2004. $240 \mathrm{p}$.

4. Bretherton Ch., Vogler J. The European Union as a Global Actor. London, Routledge, $2006.316 \mathrm{p}$.

5. Chané A., Hauser A., Jaraczewski J., Jóźwicki W., Kędzia Z., Šimáková M., Suchocka H., Wallace S. EU Engagement with other European Regional Organisations. European Commission. Work Package No. 5 - Deliverable no. 2, LargeScale FP7 Collaborative Project, GA No. 320000, 2016.

6. Chané A., Sharma A. Universal Human Rights. Exploring Contestation and Consensus in the UN Human Rights Council // Human Rights \& International Legal Discourse. 2016. Vol. 10. No 2. Pp. 219-247.

7. De Schutter O. Human Rights and the Rise of International Organisations: The Logic of Sliding Scales in the Law International Responsibility. In Jan Wouters et al. Accountability for Human Rights Violations by International Organizations. Antwerpen, Intersentia, 2011. Pp. 55-129.

8. Gauttier P. Horizontal Coherence and the External Competences of the European Union // European Law Journal. 2004. Vol. 10. No. 1. Pp. 23-41. DOI: 10.1111/j.1468-0386.2004.00201.x

8. Gebhard C. Coherence. In Hill C., Smith M. International Relations and the European Union. Oxford, Oxford University Press, 2011. Pp. 101-127.

10. Gómez Isa F., Churruca C., Wouters J. EU Human Rights and Democratization
Policies: Achievements and Challenges. Abingdon, Oxon: Routledge, 2018. 188 p. DOI: $10.4324 / 9781315110769$

9. Gstöhl S. "Patchwork Power" Europe: The EU's Representation in International Institutions // European Foreign Affairs Review. 2009. Vol. 14. No 3, Pp. 385-403.

12. Исполинов А. Суд Европейского Союза против присоединения ЕС к Европейской конвенции по правам человека (причины и следствия) // Международное правосудие. 2015. № 1. С. 118-134.

13. Kolb M. The European Union and the Council of Europe. Basingstoke: Palgrave Macmillan, 2013. 232 p. DOI: 10.1057/9781137023636

14. Моисеева Д. Взаимодействие Европейского союза с международными организациями в контексте организационной теории // Вестник Пермского университета. 2018. № 12(4). С. 153-165.

15. Niemann A., Bretherton Ch. EU External Policy at the Crossroads: The Challenge of Actorness and Effectiveness // International Relations. 2013, Vol. 27. No. 3. Pp. 261-275. DOI: 10.1177/0047117813497306

16. Schumaher B. The Influence of the Council of Europe on the European Union: Resource Exchange and Domain Restriction as Venues for Inter-Institutional Influence. In Costa O., Jørgensen, K. The Influence of International Institutions on the EU. Basingstoke, Palgrave Macmillan, 2012. Pp. 186-206. DOI: 10.1057/9780230369894

17. Smith K. EU Member States at the UN: A Case of Europeanization arrested // Journal of Common Market Studies. 2017. Vol. 55. No. 3. Pp. 628-644. DOI: 10.1111/jcms. 12504

18. Smith K. The European Union and the Politics of Legitimisation at the United Nations // European Foreign Affairs Review. 2013. Vol. 18. No. 1. Pp. 63-80.

19. Stivachtis Y., Habegger, M. The Council of Europe: The Institutional Limits of Contemporary European International Society // Journal of European Integration. 2011. Vol. 33. No. 2. Pp. 159-177. DOI: $10.1080 / 07036337.2011 .543524$ 
20. Storgaard L. EU Law Autonomy versus European Fundamental Rights Protection On Opinion 2/13 on EU Accession to the ECHR // Human Rights Law Review. 2015. Vol. 15. No. 3. Pp. 485-521.

21. Tuominen H. The Role of the European Union at the United Nations Human Rights Council. Helsinki: Academic Dissertation, Unigrafia, 2016.

22. Wouters J., Chané A., Ramopoulos T. Improving the European Union's Status in the United Nations and the UN System: An Objective Without a Strategy. In Kaddous Ch. The European Union in International Organisations and Global Governance. Oxford, Hart Publishing, 2015. Pp. 45-74.
23. Wouters J., Meuwissen K. The European Union at the UN Human Rights Council: Multilateral Human Rights Protection Coming of Age // European Journal of Human Rights. 2014. No. 2. Pp. 135-172.

24. Zaru D., Geurts Ch. Legal Framework of EU Participation in Global Human Rights Governance. In Wouters J., Bruyninckx H., Basu S., Schunz S. The European Union and Multilateral Governance. Basingstoke, Palgrave Macmillan, 2012. Pp. 49-65. DOI: $10.1057 / 9780230375918$

25. Жулева М., Лазутина Т. Человек и его права в контексте современной реальности // Вестник Томского государственного университета. 2017. № 418 . C.202-207.DOI:10.17223/15617793/418/26

\section{About the author:}

Анатолий Сергеевич Бояшов - научный сотрудник Билефельдского университета, 33615, Германия, Билефельд, Университетштрассе 25.

E-mail: anatoly.boyashov@uni-bielefeld.de. 